Revista Iberoamericana, Vol. LXVIII, Núm. 199, Abril-Junio 2002, 367-392

\title{
PROFILAXIS, TRADUCCIÓN Y ÉTICA: \\ LA HUMANIDAD “DESECHABLE” EN RODRIGO D, NO FUTURO, LA VENDEDORA DE ROSAS Y LA VIRGEN DE LOS SICARIOS
}

\author{
Carlos A. Jáuregui \\ Vanderbilt University \\ JuAna SuÁRez \\ University of North Carolina, Greensboro

\begin{abstract}
...corría una quebrada descubierta, uno de esos arroyos de Medellín otrora cristalinos y hoy convertidos en alcantarillas [...] arrastrando en sus pobres aguas la porquería de la porquería humana”

Fernando Vallejo, La virgen de los sicarios

La aproximación del rostro es la forma más básica de responsabilidad. [...] el rostro es el Otro que me pide que no lo deje morir solo, como si de hacerlo me hiciera cómplice en su muerte.

Emmanuel Lévinas, “Ethics”

Yo hago cine con eso que otros dejan de lado.

Víctor Gaviria,

"Violencia, representación y voluntad realista"
\end{abstract}

DESECHO, NEORREALISMO Y “PORNOMISERIA”

En la vigésimo cuarta Bienal de São Paulo (1998), cuyo eje conceptual y núcleo histórico fue la amplia gama semántica del tropo canibalismo, Vik Muniz, del Brasil, presentó varios montajes fotográficos de niños de São Paulo compuestos con basura, proponiendo un contraste entre el canibalismo social del consumo —una reformulación de la metáfora gótica marxista sobre la avidez del capital—y los desperdicios humanos que este consumo produce cuando se imagina sin límites económicos, ecológicos y políticos. El consumismo anuncia para Muniz una catástrofe en las renovadas periferias del sistema global: la catástrofe de la humanidad “desechable,” residuo del mercado bajo la intensa lógica y la violencia del capital. Frecuentes noticias de operaciones de "limpieza social” —un eufemismo para el asesinato de niños de la calle o delincuentes juveniles de las favelas, las comunas, los barrios marginales, etc.- acompañaron desde mediados de los años ochenta la intensificación global del capitalismo en América Latina. Entre los discursos cotidianos sobre la marginalidad y la criminalidad urbana emergió con renovadas fuerzas una imagen: la de la ciudad como un lugar contaminado no por los ruidos y la 
polución industrial de la modernización periférica, ${ }^{1}$ ni por los residuos petroquímicos de los motores que la cruzan, sino por una “polución humana.” Para la ciudad letrada de las últimas décadas del siglo pasado, el malestar por la ciudad fue frecuentemente un malestar de lo nacional ${ }^{2}$ frente a las muchedumbres democráticas, la plebe, los inmigrantes, y la abigarrada heterogeneidad lingüística, étnica y política de la multitud. En las últimas décadas del siglo xx, ese imaginario se renueva con las constantes referencias a una ciudad sucia de humanidad, asediada, infectada e infestada de "elementos indeseables". Las metáforas deshumanizadoras se multiplican como en el pasado: "ratas”, "peste”, "escoria”, "basura”, “infección”. Finalmente, la lógica cultural del capitalismo tardío y de la sociedad de consumo, ha dado con un tropo rotundo: “desechables”. La ciudadanía es una condición política definida por sustracción, por la marca, separación y disposición de la marginalidad social como desecho humano.

Propiamente hablando, el "desechable” es el opuesto constitutivo de la nacionalidad. En el caso de los “desechables” resulta fatalmente exacta la proposición según la cual el consumo define identidades. Los “desechables” son identificados por el ciudadano pleno con los residuos, y consecuentemente ubicados más allá de la mirada, en los confines o “tugurios” de la representación y el reconocimiento social. Esa desaparición no solamente ocurre en el imaginario. Los comerciantes sienten esa "polución” en sus niveles de ventas, los políticos prometen "reubicaciones", y pasan buldózers sobre las casas de cartón borrando, limpiando, aquí y allá. No siempre esa profilaxis es oficial o urbanística, como indican los homicidios de gamines (o niños de las calles) y jóvenes desempleados e indigentes balaceados mientras duermen debajo de un puente; de las prostitutas y muchachos que venden su cuerpo y de los travestis engalanados para una fiesta con la muerte que se baja de una camioneta con su metralla; de los drogadictos concentrados en una botella de pegamento; de los dementes sucios y semidesnudos que recorren la ciudad con sus miradas que la ciudad teme ${ }^{3}$ (Jáuregui, “Del ca(n/l)ibalismo y la Antropofagia, al consumo").

Un interés antropológico por la alteridad “que nos habita” en el espacio urbano y una estética del desecho — que tiene por objeto la violencia y la marginación económica y los

\footnotetext{
${ }^{1}$ En la introducción a Cities and Citizenships, Holston y Appadurai señalan que para hablar de las ciudades contemporáneas y los procesos urbanos es necesario repensar las limitaciones que implica hablar de fordismo (y post-fordismo) respecto a algunas ciudades latinoamericanas cuyo desarrollo no tiene mucho que ver con los desarrollos de la industria, la manufactura y la producción, sino que son más bien centros comerciales, financieros, burocráticos y militares (13-14).

${ }^{2}$ Como lo recuerdan Holston y Appadurai, desde el siglo xvir la categoría de "ciudadanía” como relación de pertenencia plena está asociada a la de "nacionalidad" (1). Para los autores, las ciudades siguen siendo sitios especialmente privilegiados para considerar las renegociaciones actuales del concepto de nacionalidad en las reconfiguraciones globales (2-3).

3 "There is a broad criminalization of the poor at the same time that social groups at all levels come to support the privatization of security and the extralegalization of justice as the only effective means to deal with 'marginals'. In other words, there is a massive support for market forms of justice on the one hand (private security, vigilantes, enforcers) and, on the other hand, for extralegal and even illegal measures of control by state institutions, particularly the police (and related death squads) who kill large number of 'marginals'. This kind of violence further discredits the justice system and with it the entire project of democracy and its citizenship" (Holston y Appadurai 15).
} 
cuerpos residuos o "desechables" de la ciudad- parece ocupar a críticos, novelistas, violentólogos y directores de cine. La aparición de Rodrigo D. No futuro (1989) del director colombiano Víctor Manuel Gaviria (1955-) de cierto modo anticipa en la escena cultural colombiana una serie de novelas, ensayos y libros de crítica sobre la vida de las comunas y zonas marginales de Medellín, la marginalidad residual de las ciudades y sus flujos de violencia. A lo anterior se suma el número de trabajos analíticos producido por especialistas en "violentología”, un campo de investigación local, con expertos en el tema (sociólogos, antropólogos y comunicadores sociales) denominados “violentólogos” (ver Suárez, "Bajo el lente de Gaviria” 2000). Dentro de esa extensa producción, vale la pena mencionar el estudio-testimonio No nacimos pa' semilla (compilado por Alonso Salazar, 1990) y tres novelas: La virgen de los sicarios (1994) de Fernando Vallejo, llevada al cine por Barbet Schroeder (La virgen de los sicarios 2000), Rosario Tijeras (1999) de Jorge Franco Ramos y, del propio Víctor Gaviria, El peladito que no duró nada (1991), una adaptación del guión de la película Rodrigo D basada en el relato de Alexander Gallego. Posteriormente, Víctor Gaviria dirigió La vendedora de rosas (1998), el segundo largometraje de lo que el director espera será una trilogía sobre marginalidad y violencia en la ciudad, las generaciones “consumidas por la violencia," la vida de los niños de la calle, la cultura del "traqueteo"” y el narcotráfico ("Violencia, representación y voluntad realista”).

Algunos de los trabajos mencionados han ido, además, tras los cuerpos sufrientes del desecho, ya para traducirlos en las disciplinas explicativas de lo social y cultural (paternalismo epistemológico), ya para proponer una agenda de redención social (normalización), ya para conjurar y exorcizar con imágenes lo que se percibe como un desastre (un ejercicio de redención simbólica). En las películas de Víctor Gaviria encontramos hasta cierto punto gestos en uno u otro sentido; sin embargo, pensamos que el proyecto de narración cinematográfica de Rodrigo $D$ y de La vendedora es otro: por un lado, hacer explícitas y cruzar las fronteras internas de la ciudad entre el ciudadano pleno y el habitante de los espacios urbanos del desecho donde han prosperado las comunas; y, en segundo lugar, promover una mirada-encuentro con el desecho humano borrado de la escena ciudadana, del imaginario de la ciudad y — a menudo— de la vida.

Quisiéramos primero situar el cine de Gaviria dentro de la tradición fílmica neorrealista de América Latina y, asimismo, anotar aspectos particulares de su obra que lo distinguen de esta tradición; y luego, hacer una lectura de sus películas recientes en contrapunto con ejemplos específicos de la producción cultural colombiana sobre la violencia.

En Gaviria existe una gran deuda formal con los documentales de los años cincuenta, así como con el neorrealismo italiano y la manera como éste fuera reformulado en México por Luis Buñuel, principalmente en Los olvidados (1950), así como con el Nuevo Cine Latinoamericano. La herencia de Buñuel se hace palpable en algunos de los procedimientos

\footnotetext{
${ }^{4}$ Actualmente, Gaviria se encuentra rodando Sumas y restas sobre la “cultura del traqueteo” durante los años de la guerra al narcotráfico. Como lo define la carpeta de promoción publicitaria de esta película, la palabra “traquetos” "proviene del ruido que producen las ametralladoras al disparar”. En la cultura del narcotráfico, explica la carpeta, se llamaba así a aquéllos que en la década de los años ochenta "traficaban con coca y desparramaban millones de dólares sobre la ciudad para comprar todo lo que se les atravesara”.
} 
de trabajo de Gaviria; particularmente en la mirada émica o “interior” (desde el sector social específico representado), en la opción de imágenes de depravación y escasez, y en la voluntad de despojar el cine de las utopías nacionales, de las representaciones sentimentalistas de la delincuencia y de las romantizaciones estéticas o políticas de los sectores marginales. Asimismo, y hasta cierto punto, Gaviria continúa la tradición del cine neorrealista acogida por los directores del Nuevo Cine Latinoamericano como Tomás Gutiérrez Alea (Cuba), Fernado Birri (Argentina), Humberto Solás (Cuba), Jorge Sanjinés (Bolivia), y Héctor Babenco (Argentina-Brasil), entre otros. ${ }^{5}$

Valga la pena señalar que pese a sus gestos neorrealistas e influencia de directores italianos como de Sica y Rossellini, el Nuevo Cine Latinoamericano no fue una continuación directa y puntual del neorrealismo italiano, sino que sufrió un proceso de acomodamiento en contextos y momentos políticos diferentes. Mientras que en Italia el neorrealismo se fundó en una agenda antifascista (John Hess 107), la producción de los directores del Nuevo Cine Latinoamericano surge como un modelo "anti-hollywoodense" ${ }^{6}$ y dentro de un contexto revolucionario en el cual muchos de los cineastas participaron. ${ }^{7}$

Antes de Rodrigo D. No futuro (1989) Gaviria había dirigido varios documentales ${ }^{8}$ en los cuales podemos encontrar ya su interés por los sectores marginales de la ciudad y sus habitantes. La forma de estos documentales encuadraría dentro de diferentes clasificaciones de la tipología establecida por Julianne Burton (1989), y dentro del detallismo e "imparcialidad" de lo que ella denomina modo observacional. ${ }^{9}$ Algunos trazos de los largometrajes Rodrigo D y La vendedora de Gaviria siguen inscritos en ese entusiasmo documental del Nuevo Cine Latinoamericano. ${ }^{10}$ Vale la pena señalar que en

\footnotetext{
${ }^{5}$ La poética neorrealista de algunos de estos directores se relaciona, además, con su formación como cineastas en el Centro de Estudios Experimentales de Roma en los años cincuenta y sesenta.

${ }^{6}$ El Nuevo Cine Latinoamericano — nos recuerda Ana M. López-buscaba alejarse del modelo dominante de Hollywood, caracterizado según la autora por la "transparencia, ilusionismo, comercialismo y brillo”, y que resultaba inapropiado para "las prácticas cinemáticas que buscaban promover la liberación sociopolítica” (407).

${ }^{7}$ En su comparación entre El ladrón de bicicletas (1948) y Yawar Mallku (Jorge Sanjinés, Bolivia1969), Hess establece algunos de los principales puntos de intersección así como diferencias entre el neorrealismo italiano y el cine latinoamericano: "The films demonstrate the convergence and synthesis of arts and politics so common in revolutionary situations and in Latin America in the last several decades. Thus these films, unlike the neo-realist films, focus on choice and people who choose" (115-116).

${ }^{8}$ Para una lista parcial de la trayectoria de Víctor Gaviria como documentalista, ver la introducción a la entrevista con el director "Violencia, representación y voluntad realista." Recientemente, Gaviria compiló su trabajo documental para ceder los derechos de emisión a la televisión colombiana así como para fomentar el proyecto pedagógico "La maleta del cine colombiano" que busca presentar, en diferentes ciudades, el legado general de los cineastas colombianos, incluyendo desde sus obras menos conocidas hasta los trabajos que les han brindado reconocimiento nacional e internacional.

${ }^{9}$ Según la autora, esta categoría se caracteriza por el énfasis en la imparcialidad y por el "intimate detail and texture of lived experiences, behavior of subjects within social formations (families, institutions, communities), and at moments of historical or personal crisis" (4).

${ }^{10}$ Para López, el documental como componente de estas películas funciona como "a springboard for the movement's transformation and retheoretizing of the cinematic apparatus and its social functions" (404).
} 
el caso colombiano ese tipo de trabajo y modo de representación ya habían sido ensayados en producciones anteriores con las que Gaviria dialoga, si bien no de manera expresa o consciente. Pensamos particularmente en el documental Chircales realizado por los antropólogos Marta Rodríguez y Jorge Silva durante 1968 y 1970, ${ }^{11}$ y en Gamín (1977) dirigida por Ciro Durán. En Chircales se vislumbraban preocupaciones, temáticas y problemas éticos que, aunque marcados por otras circunstancias socioeconómicas, son latentes en la obra de Gaviria: el interés que tenían estos directores por entablar un trabajo comunicativo con sus actores, la intención de que "la cámara no modificara la vida de ellos en ese momento” (Caicedo 407), la coparticipación con la comunidad y, en particular, la voluntad — problemática— de hacer cine "realista”. ${ }^{12}$

Ahora bien, como coinciden en señalar diferentes críticos, ${ }^{13}$ la discusión generada en torno al Nuevo Cine Latinoamericano en su momento estaba permeada por el lenguaje político del contexto revolucionario de esas décadas, incluyendo postulados como la toma de conciencia, la movilización de las masas, etc.

When we think of the New Latin American Cinema, certain images and adjectives immediately come to mind: a bearded guerrilla, weapon in hand and ammunition belt across his chest; a crowd of peasants defiantly holding up their weapons in protest; a mass demonstration with banners weaving. If asked to describe the New Latin American Cinema, we might enlist one of the suggestive phrases that Latin American filmmakers have coined to describe their own practices: an aesthetics of hunger, a cinema of poverty, the camera as gun, an imperfect cinema, an aesthetics of garbage (López 403-4).

En las diferentes manifestaciones del cine latinoamericano desde mediados de los años cincuenta hasta finales de los años ochenta — como el Cinema Novo de Brasil, la primera generación de cineastas del ICAIC de Cuba, la Escuela Documental de Cine de Santa Fe, Argentina - encontramos el trabajo de directores políticamente comprometidos en busca de un cine con “conciencia crítica” y función social (López 407). Pero aunque gran parte de la producción del Nuevo Cine Latinoamericano aparece con una agenda explícitamente combativa y ligada a los movimientos de izquierda, ${ }^{14}$ no debemos olvidar

\footnotetext{
${ }^{11}$ Este documental tuvo "una copia final en marzo de 1972” como lo registra la entrevista de Andrés Caicedo con los directores (406).

${ }^{12}$ Durante dos años, Rodríguez y Silva visitaron continuamente la zona marginal de Tunjuelito (hoy en día incorporada plenamente a la zona urbana de Bogotá), observaron la vida, trabajo y explotación del trabajo de los fabricantes de ladrillos. Luego del trabajo de observación, recopilación de datos por medio de entrevistas y convivencia en el sector, los directores optaron por elevar una denuncia social por medio del relato fílmico-documental de la historia de la familia Castañeda. Como lo manifiestan Rodríguez y Silva, su trabajo estaba altamente ligado a las luchas políticas de ese tiempo y su origen fue el trabajo político que Rodríguez realizara en ese tiempo junto al sacerdote guerrillero Camilo Torres. En Gamín, Durán con similares preocupaciones, sigue de cerca la rutina de una "gallada" (un grupo de gamines o niños de la calle) y de habitantes de la calle que vivían del reciclaje en los basureros.

${ }^{13}$ Véanse los trabajos de Ana María López, Michael Chanan, John Hess y Julianne Burton.

${ }^{14}$ El ejemplo más contundente es el cine cubano posrevolucionario que, conforme al minucioso análisis de Michael Chanan, convierte al ICAIC en una especie de "laboratorio de prueba" para
} 
que, como resultado de la censura impuesta por los gobiernos de este período, varios directores se abstuvieron de ponerse políticamente en evidencia. ${ }^{15}$ Para David Ranghelli, Pixote (Héctor Babenco, Argentina/Brasil, 1980) y Macu (Solveig Hoogejstein, Venezuela1985) junto a Gamín y Rodrigo D, son producciones en las que se ve esta inclinación neorrealista de algunos directores de presentar la brutalidad de los hechos sin hacer explícitas sus proposiciones políticas (13).

Algunas de las prácticas del Nuevo Cine Latinoamericano persisten en el trabajo de Gaviria pero, en términos generales, puede decirse que se aleja de muchas de las premisas políticas y de compromiso de éste, y que el "neorrealismo" de Gaviria corresponde mejor a la fractura que a las propuestas y agendas de liberación y representación popular de los sectores de izquierda de los años sesenta y setenta. En las películas de Gaviria, por ejemplo, ya no será posible hablar del imperialismo cultural, ni en términos de (neo)colonialismo o dependencia cultural. Como se sabe, el Nuevo Cine Latinoamericano insistió en los antagonismos entre la burguesía y el proletariado, entre el opresor y el oprimido y, sobre todo, entre el imperialismo norteamericano y la cultura nacional. Los personajes de Gaviria no establecen una relación contestataria de este tipo sino que, más bien, proceden a estrategias de apropiación cultural, como ocurre en el caso de la música rock o la cultura “punk" en Rodrigo $D .{ }^{16}$

Asimismo, mientras que el constante interés del Nuevo Cine Latinoamericano es registrar y hacer una crítica política de la Historia, la preocupación de Gaviria es el registro de la memoria de individuos y sectores citadinos a punto de desaparecer. En otras palabras, se centra en la política de la historia con minúsculas, y en la experiencia humana cotidiana de sectores vistos y tratados como desecho. Como fuera el caso de Tire dié (Fernando Birri, Argentina-1958), el trabajo de Gaviria apunta a otorgar visibilidad a lo que tiende a hacerse invisible, ignorado y en ocasiones borrado. ${ }^{17}$

diferentes tipos de cine $(35,36)$. Además de cine didáctico, Chanan reseña categorías que se marcaron claramente en el cine cubano hasta 1982, mencionando entre otras, el cine celebrativo, de combate, de denuncia, de encuesta, de ensayo, de reportaje, de rescate y el mismo cine testimonio (35).

${ }^{15}$ Respecto al efecto de la censura en el Nuevo Cine Latinoamericano, Hess explica que la naturaleza del trabajo de varios de estos directores está ampliamente moldeada por su participación directa en el conflicto revolucionario y algunos de ellos (Sanjinés, por ejemplo) vivieron la experiencia de la censura, obligándolos al exilio, lo cual influye directamente en la temática y naturaleza de su trabajo (111). En el caso de Colombia, el propio Durán declara que la Junta de Censura y la Junta de Control de Calidad sumó a las constricciones ya existentes en cuanto a producción y distribución, la regulación e incidencia en la exhibición buscando aquellas películas que no atentaran abiertamente "contra el orden establecido" ("El nuevo cine colombiano" 243).

${ }^{16}$ John Beverley señala que: "It would be difficult to see Rodrigo $D$ and continue to talk about rock as a form of cultural imperialism; it is, rather, a way that the young people shown in the film live culturally their experience of proletarization and alienation" (Against Literature 6).

${ }^{17} \mathrm{Al}$ respecto, en su artículo "Neo-realism and New Latin American Cinema", John Hess cita una entrevista a Birri aparecida en Argentine Cinema (editado por Tim Barnard): "To Birri, to be realist meant, as it did to the Italians, 'seeing things as they are', looking at aspects of the national reality that artists had not previously looked at. 'What I wanted', Birri has said, 'was to discover the face of an invisible Argentina-invisible not because it couldn't be seen, but because no one wanted to see it’ (Barnard 68)” (citado en Hess 109). 
Tanto Rodrigo D, no futuro como La vendedora de rosas tratan, decíamos, de la "humanidad desechable"; algo que — como ocurriera con Los olvidados (1950) de Luis Buñuel —no ha sido siempre bien recibido por parte del público. ${ }^{18} \mathrm{El}$ "neorrealismo" de Gaviria ha sido llamado "pornomiseria” y considerado como el producto de un deleite morboso de la cámara en la abyección, las imágenes de la indigencia y la basura. Se asume que estas películas están “exportando una imagen” deteriorada del país y se las entiende erradamente como alegorías nacionales (ver Suárez). Dice el crítico y director colombiano Julio Luzardo:

¿Se justifica hacer una película sin ningún valor moral simplemente porque es verídica? ¿Tiene razón el periódico Le Monde en decir que esta película no tiene ningún mérito ni como documental, ni como película? Estas y muchas otras preguntas se hacen los espectadores desprevenidos ante otra incursión de Víctor Gaviria en el bajo mundo o cloaca de nuestra sociedad [...] el tema no está a la altura de los recursos técnicos (énfasis fuera del texto). ${ }^{19}$

Luzardo no oculta su asco por el "bajo mundo o cloaca de nuestra sociedad". Supone que el cine y los recursos técnicos usados en La vendedora merecerían mejor tema que el del desecho. Frente a esta crítica, resulta legítimo preguntarse si lo que le molesta al crítico es la "incursión” de la cámara de Gaviria en la "cloaca” o la de la "cloaca” en el lugar hegemónico de representación y si el motivo de disgusto es la aproximación a la basura mediante la imagen fílmica o la aproximación de la basura por este medio. A la observación respecto a que se encuentra haciendo "pornomiseria”, Gaviria ha respondido diciendo que lo que se critica en la película es su desafío a la indiferencia, a la no mirada:

No me gusta la "pornomiseria". En el mundo que exploran las películas que dirijo existe belleza, dignidad y valores sociales. Lo que quiero decir, es que a veces lo que es egoísta, brutal, horrible, lo que es abyecto, no es el mundo sino nuestra mirada indiferente, sin empatía, una mirada que diluye lo real ("Violencia, representación y voluntad realista”).

La disolución de lo real sucede en la pura imagen sin referencialidad en la que la distinción entre la representación y la "realidad” se desdibuja y sólo queda el simulacro (Baudrillard, Selected Writings 170). "En un mundo dirigido a la indiferencia, el arte no puede más que contribuir a esta indiferencia: girar en torno al vacío de la imagen” (Baudrillard, "Duelo" en Illusion, désillusion esthétique). No es sencillamente que detrás de cada imagen algo haya desaparecido, sino que "la cuestión misma de su existencia ya no tiene sentido”. Así ocurre, precisamente, en buena parte de la producción cultural reciente sobre la violencia de las comunas de Medellín.

${ }^{18}$ Sobre la reacción del público frente a Los olvidados, véase Mi último suspiro de Luis Buñuel (24245).

${ }^{19}$ Los énfasis de las citas son añadidos salvo que se indique otra cosa. 
TESTIMONIO, ASEDIOS A LA “REALIDAD” y FICCIÓN PARTICIPATIVA

Podría decirse que Rodrigo D y La vendedora propician actos de auto-representación en algunos sentidos similares a los del testimonio: la película es concebida como acto de enunciación participativo organizado por el director y los procedimientos usados para la construcción del guión así como la producción de las películas recuerda a veces procedimientos similares a los del testimonio. Por ejemplo, se graban narrativas marginales, se usa el skaz o simulacro de una narrativa oral que recoge las particularidades del parlache $^{20}$ y los sujetos “involucrados” contribuyen a la elaboración del guión cinematográfico, como informantes o en calidad de actores naturales. ${ }^{21}$ Este paralelo no es, claro, del todo apropiado; la calificación de esas películas como testimoniales es desafortunada. El guión de las películas es expresamente presentado como una ficción; éstas no son ni se anuncian como edición de narrativas verídicas sino como relatos fílmicos ficticios. ${ }^{22}$ Aquí Gaviria ha diferenciado entre el argumento-guión de la película y los relatos, colaboración y actuación de los actores naturales. Las películas de Gaviria no pretenden narrar una historia verídica ni aspiran a ser los relatos mismos sobre los cuales se construyen o un simulacro de los mismos. Los procedimientos testimoniales son usados dentro de lo que Gaviria llama voluntad realista:

Se que es problemático hablar de realismo. Digamos que en películas como Rodrigo $D$ o La vendedora lo que tenemos es una voluntad realista y un imperativo ético respecto a la representación, que dan lugar a la construcción colectiva de relatos fílmicos. El realismo de mis películas no es la narración costumbrista o truculenta, ni el documental. El realismo ha sido mal entendido como objetividad, como voluntad de calco, como simplificación y falta de complejidad. Creo, por el contrario, que no hay nada más complicado y ambiguo, nada menos aprehensible y más difícil de representar que la realidad, y que el realismo como yo lo entiendo — es decir como voluntad de realismoasume que esa realidad no es manipulable, que es fragmentaria, que no tiene un significado estable ni abarcable, pero que sin embargo tiene cosas que decir ("Violencia, representación y voluntad realista”).

En las películas de Gaviria la ficción es explícita y asumida como tal (lo que no sucede en el testimonio). El espacio de lo "Real” está “afuera de la película” y del acto de representación. El actor natural señala esa exterioridad inefable del texto fílmico:

El argumento puede ser ficción, la historia es verdad. No se trata de una alusión a la verdad sino de una verdad enorme que sería imposible sin la presencia de estos niños en la película. De allí la intranquilidad de muchos espectadores después de ver la película y la

\footnotetext{
${ }^{20}$ Jerga de las comunas y niños de la calle de Medellín. Véase "VIOLENCIAS JUVENILES: ¿contraculturas o hegemonía de la cultura emergente?” de Alonso Salazar.

${ }^{21}$ Un actor natural -por oposición a uno profesional o aficionado- es el actor que representa un personaje acudiendo a la experiencia vital de su propia vida que guarda alguna similitud o cercanía socio-cultural con la de los sujetos representados.

${ }^{22}$ En el caso de La vendedora de rosas se trata de una adaptación del cuento infantil "La vendedora de cerillas” de Hans Christian Andersen.
} 
mía después de hacerla. La vida es más triste, más dura, más alegre; escapa necesariamente a la película e incluso a nuestro intento de comprenderla o hallarle significado. El actor natural señala ese afuera de la película, siempre inasible ("Violencia, representación y voluntad realista”).

La distancia del trabajo de Gaviria del testimonio se hace evidente en el documental Cómo poner a actuar pájaros sobre la producción de la película y sobre Mónica Rodríguez (cuyas historias ayudaron a la elaboración del guión de La vendedora de rosas). Allí aparece documentado el proceso de recepción del “testimonio": vemos a Gaviria filmando, grabando y tomando notas del relato autobiográfico de Rodríguez. Pero Rodríguez no protagoniza la película sino que facilita al director y su equipo el acercamiento al entorno de estas niñas y colabora en el casting. De hecho, Rodríguez se convierte en una de las asistentes de dirección de la película hasta que es asesinada poco después. Rodríguez como sujeto del testimonio expresa: "todo lo que se muestra en La vendedora de rosas es verdad. Ahí todo es real, nada es mentira, hay cosas cambiadas porque hay cosas que no se pueden mostrar... porque hay cosas peores" (Cómo poner a actuar pájaros). Esas "cosas cambiadas," o petites histoires son re-narradas como ficción neorrealista y mediatizadas cinematográficamente.

Rodrigo D y La vendedora se sitúan políticamente en lo que Roland Barthes llamó ambigüedad política. Extrapolando su análisis podría decirse que así como el "proletario" de Chaplin es aún "el hombre con hambre", y no es propiamente un proletario sino un pobre, los sujetos de las películas de Gaviria están siempre "más acá de la conciencia política” (39). Ellos están antes del telos épico del testimonio, ${ }^{23}$ en la rebeldía errática de los personajes de Rodrigo $D$ o en el final suicida del protagonista. Los actores naturales de La vendedora, como explica Gaviria en Cómo poner a actuar pájaros, expresan una rebeldía amorfa sin una agenda específica ni coherente. Al narrar sus vivencias personales, estos actores no aspiran a posicionarse en un papel conspicuo, ni a asumir la voz de la colectividad o a enunciarla políticamente o abanderar un movimiento de resistencia social o de protesta como los del Nuevo Cine Latinoamericano; el acto de representación apenas desafía la borradura, el olvido.

Puede alegarse que el testimonio en cierta medida fue convertido en un artefacto cultural expiatorio o de redención política de un sector académico que —aunque se confiesa yuppie como hace John Beverley—se llama a sí mismo “intelligentsia radicalizada” y plantea una "alianza política” con sectores populares y subalternos; mediante esa alianza se le daría voz en la literatura a un sujeto "anónimo y popular-democrático" (Against Literature 78, 88). Esta concepción del testimonio ve en dicha “alianza” la posibilidad de desarrollo de "movimientos de resistencia”, y presupone que éste es una forma de narrativa "fundamentalmente democrática e igualitaria", y no el producto de un paternalismo letrado-académico que funciona verticalmente y que asume que la política pasa siempre por la universidad (especialmente la universidad estadounidense) y por formas hegemónicas

\footnotetext{
${ }^{23}$ Para Beverley, el narrador en el testimonio "speaks in or for the name of a community or group, approximating in this way the symbolic function of the epic hero without at the same time assuming his hierarchical and patriarchal status” (Against Literature 74).
} 
de producción cultural y representación..$^{24}$ De la misma manera implica que existe un cambio cualitativo entre la definición de la función del intelectual liberal como lengua protésica (que habla por el Otro) y como intelectual megáfono (que le “da” voz al Otro o lo hace audible ${ }^{25}$ ). Por último, esta concepción del testimonio supone que el sujeto al cual el testimonio le "da voz" tiene una agenda, que esa agenda es revolucionaria y/o políticamente "positiva”, y que mediante el artefacto del libro-testimonio se hace inteligible $\mathrm{y}$ - al menos en parte- efectiva. Nos encontramos con un descenso al subalterno para elevarlo, darle una voz y hacerlo audible. En el correlativo y subsiguiente ascenso que implica esta supuesta alianza, la voz narrativa del subalterno se hace "metonímica" de un sector social (representación), el "gestante” del testimonio se redime y la "intelligentsia yuppie radicalizada” le da un sentido existencial a la profesión académica: la traducción cultural.

ININTELIGIBILIDAD RADICAL VERSUS TRADUCCIÓN

Ahora bien, ¿corresponde el neorrealismo de Gaviria a la idea de simulacro y a la búsqueda de redención en la basura? ${ }^{26}$ En otras palabras, ¿desaparece la "realidad” en el “realismo” de las imágenes del Otro, contribuyendo a la indiferencia y desilusión radical que implica la lógica cultural del capitalismo tardío? Quisiéramos plantear que el proyecto narrativo y fílmico "neorrealista" de Gaviria representa una disidencia frente a la producción cultural sobre la violencia. Mediante lo que Gaviria llama "construcción colectiva de relatos fílmicos”, sus películas intentan resistir el simulacro y la cosificación esteticista y erotizadora del "desecho humano", y no caer en la explicación socioantropológica. En otras palabras, esas producciones apuntan, si bien de manera irregular, a una ética y no a una estética o a una antropología políticamente correcta o testimonial.

Debe reconocérsele a Gaviria la honestidad intelectual con la que asume la intraducibilidad de lo que él llama "real” en una proposición política o en una antropología explicativa. En esa intraducibilidad, que acompaña el acto de representación, radica gran parte de la complejidad y de las aporías de su trabajo:

La ficción es el rodeo que hacemos a través de la imaginación para llegar a la verdad de lo que está aquí mismo, a la verdad de la elusiva realidad nuestra de todos los días [...]. La realidad tiene esta doble condición: está ahí, cotidiana, mostrándonos la cara, pero al mismo tiempo es elusiva en sus significados, indescifrable ("Víctor Gaviria por Víctor Gaviria” 6).

\footnotetext{
${ }^{24} \mathrm{El}$ testimonio se apropiaría de formas discursivas dominantes para posibilitar la existencia política de esas voces (Against Literature 86).

${ }^{25}$ El subalterno del testimonio, según Beverley, coincidiría con una extensa galería de voces que le hablan a la hegemonía (Subalternity and Representation 116). Ello ocurre, "gracias” a la mediación de un sector "radicalizado" de la propia hegemonía que sirve de médium a la voz del subalterno. 26 "Es como si el arte, como si la historia, hicieran sus propios basureros y buscaran su redención en los detritus" ("Duelo"). Baudrillard se refiere a un cine de excesos realistas y virtuosismo técnico, que producen una "pornografía de la imagen” y un "estereotipo realista” en el que las imágenes paradójicamente pierden todas las huellas.
} 
Gaviria es un director preocupado con el lenguaje de los Otros y por las disonancias de los espacios marginales de la ciudad. En diferentes declaraciones y entrevistas ha defendido su opción de presentar el lenguaje de niños de la calle, sicarios y pistolocos sin concesiones con el espectador. Gracias a la participación de actores naturales, las películas sitúan al espectador en medio de la violencia, el vértigo y la "monstruosidad del habla”:

Ese lenguaje — que está relacionado tan fuertemente a la identidad de estos niños—tiene algo de monstruoso; esa, creo, es la violencia lingüística que sienten algunos espectadores. Yo no puedo sin traicionarme, hacer de corrector del habla, y de gramático y preceptor del buen decir de los actores naturales. Ese lenguaje es mucho más importante que la película misma porque allí está la historia (la de la ciudad, la de los muchachos, la de los muertos, la de la injusticia, la de las experiencias de vida, la de la solidaridad y la identidad) ("Violencia, representación y voluntad realista”).

Esa ininteligibilidad radical es inseparable del acto de representación participativa. Pero Gaviria está consciente de que si bien la "estructura de estas narraciones y su orden tiene que ver con lo oral” el resultado "no [es] equivalente a la oralidad de la que el trabajo surge, sino una construcción con base en ella" ("Violencia, representación y voluntad realista”).

Examinemos esta (in)inteligibilidad en contrapunto con otros trabajos fílmicos y literarios sobre la violencia, la marginación económica, los cuerpos residuos o “desechables” de la ciudad y la marginalidad lingüística del mundo cultural de las comunas: La virgen de los sicarios (Fernando Vallejo, 1994), la película del mismo nombre dirigida por Schroeder, y Rosario Tijeras (Jorge Franco Ramos, 1999).

La virgen de los sicarios realiza un movimiento doble y contradictorio: por una parte marca el lenguaje (y la cultura) como algo ajeno ${ }^{27} \mathrm{y}$, por otro, procede a su traducción. Fernando, el narrador-personaje, es un outsider ${ }^{28}$ que se adentra en el mundo del sicariato por medio de sus relaciones amorosas otoñales con dos jóvenes sicarios: Alexis y luego Wílmar, asesino del primero.

Fernando actúa como una especie de médium literario de la alteridad pre-letrada, de la voluptuosa oralidad y de la violencia de las comunas:

No habla español, habla en argot o jerga. En la jerga de las comunas o argot comunero que está formado en esencia de un viejo fondo de idioma local de Antioquia [...] más una que otra supervivencia del malevo antiguo del barrio de Guayaquil, ya demolido, que hablaron sus cuchilleros ya muertos; y en fin, de una serie de vocablos y giros nuevos, feos, para designar ciertos conceptos viejos: matar, morir, el muerto, el revolver, la policía... Un ejemplo: “¿Entonces qué parce, vientos o maletas?” ¿Qué dijo? Dijo: “Hola hijo de puta”. Es un saludo de rufianes (Vallejo 26).

\footnotetext{
${ }^{27}$ Al comienzo de la novela, el protagonista exclama: “¿Pero por qué me preocupa a mí Colombia, si ya no es mía, es ajena?” (Vallejo 9).

${ }^{28} \mathrm{El}$ narrador ve las comunas desde la terraza de su apartamento y las apropia en una ensoñación erótica: "Yo hablo de las comunas con la propiedad de quien las conoce, pero no, solo las he visto de lejos, palpitando sus lucecitas en la montaña [...]. Las he visto soñando, meditando desde las terrazas de mi apartamento, dejando que su alma asesina y lujuriosa se apodere de mí" (34).
} 
El narrador marca durante todo el texto la anomalía del lenguaje de los habitantes de Medallo / Metrallo, esa ciudad-Otra que asedia a Medellín; asimismo, se interrumpe constantemente para explicar el significado de algún término y hacer correcciones en el habla de los otros personajes. Desea — según confiesa — llevar al lector por la novela como si éste fuera un turista. Así, este guía turístico-literario adopta el papel de traductor privilegiado:

\footnotetext{
“El pelado debió de entregarle las llaves a la pinta esa”, comentó Alexis, mi niño, cuando le conté el suceso [...]. Y yo me quedé enredado en su frase soñando, divagando, pensando en don Rufino José Cuervo y lo mucho de agua que desde entonces había arrastrado el río. Con "el pelao" mi niño significaba el muchacho; con "la pinta esa” el atracador; y con el "debió de” significaba “debió” a secas: tenía que entregarle las llaves [refiriéndose a un joven asesinado por no entregarle las llaves del carro a un asaltante] (23).
}

No es gratuito que su profesión sea la de gramático, ni que Alexis, su amante, se convierta en el ejecutante de una violencia disciplinaria frente a la plebe urbana que el narrador traduce y/o "tacha" mediante una serie de homicidios. El narrador establece un lugar de privilegio lingüístico frente al lenguaje de las comunas y ostenta frecuentemente marcas de su cultura literaria mediante citas y comentarios eruditos y librescos; por ejemplo, convierte hijueputa en el cervantino hideputa (25), señala como sus pensamientos vienen a veces en "versos alejandrinos" (41) y alude constantemente a la lingüística o a la literatura como (pre)texto de su crítica culturalista del “caos” social. Desde esta posición explica la jerga, corrige la dicción y sintaxis de las comunas y ofrece acotaciones explicativas al lector dentro de la narración. La traducción es tan insistente como el homicidio: “¡Gonorreas! (Gonorrea es el insulto máximo en las barriadas de las comunas, y comunas después explico qué son)” (14).

La violencia interpretativa, gramatical y lingüística se extiende a la cultura y a los habitantes de la urbe. Es paralela a la serie de homicidios que comete el sicario para “realizar" la visión disciplinaria de la ciudad de su amante gramático. El proyecto narrativo en La virgen está edificado sobre la noción del desastre y la nostalgia por un orden ido. En la versión fílmica, dirigida por Schroeder, el trabajo de la cámara permite la construcción del narrador y sus amantes sicarios como flâneurs que se desplazan por Medellín mientras el narrador le cuenta al sicario (y al espectador) “lo que era” la ciudad. Esa nostalgia se hace sintomática en el texto fílmico con la reiteración de la frase "todo ha cambiado; ya nada es como antes”. En la Medellín cartografiada e idealizada de manera elitista, todo (las clases sociales, la religión, la familia) estaba en su lugar, antes de la "podredumbre” contemporánea. La violencia es el común denominador entre la gramática y la mirada cultural nostálgico-reaccionaria del narrador sobre la ciudad. 


\section{Profilaxis SOCIAL Y LA MÁQUINA ERÓTICA DE MATAR}

Tanto en el texto de Vallejo como en la versión fílmica —adaptación bastante textual de la novela ${ }^{29}$ - Fernando (el gramático) marca constantemente su distancia cultural frente a la "adicción” de los personajes jóvenes por el zapping y el punk y la industria cultural de masas. Fernando quiere silenciar — y silencia mediante Alexis - el equipo de sonido, la televisión, los silbidos de un transeúnte, la música rock, los vallenatos en la radio de los taxis, el lenguaje de la calle, el ruido urbano y hasta a un mimo silencioso que se burla de un transeúnte. ${ }^{30}$

El gramático es poseedor de una verdad indecible previa al "abaratamiento de la existencia” por la industria cultural de masas:

Mira Alexis, tú tienes una ventaja sobre mí y es que eres joven y yo ya me voy a morir, pero desgraciadamente para ti nunca vivirás la felicidad que yo he vivido. La felicidad no puede existir en ese mundo tuyo de televisores y casetes y punkeros y rockeros $y$ partidos de fútbol. Cuando la humanidad se sienta en sus culos ante un televisor a ver veintidós adultos infantiles dándole patadas a un balón no hay esperanzas. Dan grima, dan lástima, dan ganas de darle a la humanidad una patada en el culo y despeñarla por el rodadero de la eternidad, y que desocupen la tierra y no vuelvan más (Vallejo 15).

Fernando se erige en una especie de crítico cultural de la "cultura de masas" en la tradición de Frankfurt ${ }^{31}$ que, paradójicamente, ha devenido fascista en la "posmodernidad" ruidosa de una urbe "alienada”. La música estridente que tanto le molesta al protagonista es acallada por Alexis, el sicario amante del gramático, que se convierte en una especie de mano armada de disciplinamiento de los yerros de la "gramática” cultural de la ciudad. La violencia reorganiza momentáneamente el “orden ido”, y —mediante Alexis— limpia la ciudad de la que Fernando llama una "raza limosnera” (16):

Era la turbamulta invadiéndolo todo, empuercándolo todo con su miseria crapulosa. “¡A un lado chusma puerca! Íbamos mi niño y yo abriéndonos paso a empellones por entre esa gentuza agresiva, fea, abyecta, esa raza depravada y subhumana, la monstruoteca.

\footnotetext{
${ }^{29}$ El guión fue escrito por el mismo Vallejo y más o menos conserva el orden lineal de la novela. No hay que olvidar que por otra parte, la novela acude a imágenes y recursos cinematográficos. Vallejo estudió cinematografía en el Centro Experimental de Roma, y a finales de los años setenta y comienzos de los ochenta, hizo tres películas poco distribuidas en Colombia, dos de ellas sobre el tema de la Violencia y una fuertemente censurada por el Ministerio de Comunicaciones (Jaramillo 8, 9).

${ }^{30}$ Por ejemplo, Fernando le ordena a los taxistas apagar la radio: “Algo oían en mi tono perentorio, la voz de Thánatos, que les quitaba toda gana de disentir: o lo apagaban o lo apagaban. ¡Qué delicia viajar entre el ruido en el silencio!” (58).

${ }^{31}$ Planteada por críticos como Theodor Adorno y Max Horkheimer, esta tradición crítica desarrolló una perspectiva conocida como la de la "producción del consumo" sobre la base de la teoría de la alienación de Marx. Se pensó en el consumo como una actividad pasiva de sujetos básicamente dominados por la industria cultural y la publicidad. A la objetivación del trabajo correspondía la objetivación del consumo, que producía “una falsa identidad,” y la homogenización y abaratamiento de la existencia bajo el poder absoluto del capitalismo.
} 
[...]Y ese olor a manteca rancia y a fritangas y a gases de cloaca... ¡Qué es! ¡Qué es! ¡Qué es! Se ve. Se siente. El pueblo está presente $(75,76)$.

La parodia de las consignas de las manifestaciones populares (“Se ve. Se siente. El pueblo está presente”) está acompañada de un racismo resemantizado como asco por la multitud heterogénea de "mala sangre, de mala raza, de mala índole, de mala ley” (105). La “crítica del habla marginal” y la "crítica de la cultura de masas” — ambos discursos de la pureza — son sospechosamente paralelos al ejercicio de la violencia. El discurso de la monstruosidad y el desecho da paso al de la "condena" reaccionaria de los derechos humanos (117-20) y a la retórica de la "profilaxis social” y el exterminio. Alexis es precisamente llamado "el Ángel Exterminador que había descendido sobre Medellín a acabar con su raza perversa” (64) y disponer la solución final anhelada por el narrador:

Esta es una raza ventajosa, envidiosa, rencorosa, embustera, traicionera, ladrona: la peste humana en su más extrema ruindad. [...] Aquí nadie es inocente, cerdos. Lo mataron por chichipato, por bazofia, por basura, por existir. Porque contaminaba el aire y el agua del río. Ah "chichipato" quiere decir en las comunas delincuente de poca monta, raticas, eso. [...] ¿Tiene este problemita solución? Mi respuesta es un sí rotundo como una bala: el paredón (31-33).

Yo no le veo a este asunto más solución ni remedio que cortar como hizo Alejandro, de un tajo, el nudo gordiano, e instaurar un fusiladero: una tapia larga, larga, encalada de blanco [...]. Y que vayan cayendo los fumigados, y aterrizando sobre ellos los gallinazos (100).

La ciudad está dividida entre la ciudad de abajo, lugar de enunciación de la novela, y la ciudad de arriba que la invade. ${ }^{32}$ Esta última — que podemos llamar la ciudad-Otrason las comunas; el espacio urbano del “desecho” humano: “aquí la vida crapulosa está derrotando a la muerte y surgen niños de todas partes, de cualquier hueco o vagina como las ratas de las alcantarillas cuando están muy atestadas y no caben” (84). Nótese, sin embargo, que al mismo tiempo que las comunas son "cloacas” y espacio del desecho, aparecen "excitantes" y llenas, no ya de cuerpos abyectos ("ratas") sino de cuerpos apetecibles de jóvenes para el consumo y el comercio sexual: "De las comunas de Medellín la nororiental es la más excitante. No sé por qué, pero se me metió en la cabeza. Tal vez porque de allí, creo yo, son los sicarios más bellos” (64)..$^{33}$ El cuerpo-Otro posee, como

\footnotetext{
${ }^{32}$ El narrador de La virgen de los sicarios incesantemente reflexiona sobre la dicotomía de la ciudad: "Podríamos decir, para simplificar las cosas, que bajo un solo nombre Medellín son dos ciudades: la de abajo, intemporal, en el valle; y la de arriba en las montañas rodeándola (96). "[...] Si señor, Medellín son dos en uno: desde arriba nos ven y desde abajo los vemos, sobre todo en las noches claras cuando brillan más las luces y nos convertimos en focos. Yo propongo que se siga llamando Medellín a la ciudad de abajo, y que se deje su alias para la ciudad de arriba: Medallo" (99).

${ }^{33}$ Nótese como a una imagen se sigue la otra: "Desde esas planchas o terrazas de las comunas se divisa Medellín. Y de veras que es hermoso. Desde arriba o desde abajo, desde un lado o desde el otro, como mi niño Alexis. Por donde lo mire usted. Rodaderos, basureros, barrancas, cañadas, quebradas, eso son las comunas" (68).
} 
en el caso del tropo del salvaje, una clave fascinante: el gramático refiriéndose a Alexis dice que en él estaba la "verdad más absoluta [...]. De eso era de lo que me había enamorado, De su verdad” (21).

La lengua del Otro, así como su violencia, son complementarias, objetos del dominio epistemológico y erótico del narrador. Una suerte de economía perversa hace de Alexis, al mismo tiempo cuerpo erótico y parte de la humanidad-“bazofia”, multitud amorfa que habita el espacio urbano del desecho y que está entregada al fútbol, al ruido y a las imágenes. Al lado de su repulsión por las "ratas” y la por la "raza simiesca”, y su mareo ante el calidoscopio de la cultura de masas, el gramático siente — en el cuerpo de Alexisuna atracción erótica por esa "inocencia" entregada a la lengua "como se habla", al rock, y a la televisión. Al final el cuerpo del sicario se desdibuja paradójicamente en la melancolía de una imagen: “'Yo no sé si vas a crecer más o no niño, pero así como estás eres la maravilla. Mayor perfección ni soñarla’. La pelusita del cuerpo a la luz del sol daba visos dorados. ¡Cómo no te tomé una foto! Si una imagen vale más que mil palabras” (30).

El gramático traductor borra la escritura humana de la ciudad (el ruido, las incorrecciones lingüísticas, la falta de cortesía, la ofensa en la calle, etc.) mediante el dispositivo del Otro. Alexis, es — dice el gramático- “mi portentosa máquina de matar" (36), la máquina erótica y pre-letrada que en manos de su amante gramático dispensa la muerte y recodifica la ciudad.

A diferencia de la novela de Vallejo y la película de Schroeder, las películas de Gaviria no se instalan en la nostalgia por la ciudad "de antaño”, no funcionan en la imaginación gramática del deber ser, ni se deleitan en la violencia como dispositivo aséptico y estético frente al "desastre". ${ }^{34}$ De igual manera, el lenguaje como jerga, la música como "ruido", y la concepción de la violencia como borradura y acallamiento de la novela de Vallejo, contrastan con la inmersión en el "ruido incomprensible” que se experimenta en Rodrigo D. No futuro donde predominan la "bulla”, el rock, y la jerga comunera o parlache. Ese "ruido" sirve en Rodrigo D como principio organizador de la identidad, mientras que en la novela de Vallejo y en la película de Schroeder son síntomas de pérdidas identitarias.

En la novela Rosario Tijeras (1999) de Jorge Franco Ramos, el personaje Rosario, una joven proveniente de las comunas, sirve nuevamente como puente para que el narrador outsider pueda transitar por ese mundo (50). Rosario sostiene una relación con Emilio, un joven de clase alta, al mismo tiempo que entabla una relación cercana con Antonio, el mejor amigo de éste, de clase media. Emilio y Antonio encarnan la juventud acomodada de Medellín que se vio fuertemente involucrada en la fiesta y el consumo propiciado por el narcotráfico.

Aunque no de la misma manera que las niñas de La vendedora — que están en el riesgo constante de convertirse en mercancía humana- el cuerpo de Rosario también es un cuerpo consumible y marginal. Ella es el Otro deseado que — como Alexis en La virgen,

\footnotetext{
${ }^{34}$ Gaviria anota: "Yo no creo que Rodrigo D ni La vendedora [... ] son despiadadamente frías como de alguna manera lo es La virgen de los sicarios, que me parece una buena realización, pero que obedece a las ideas de una persona que piensa que este mundo realmente debería desaparecer del todo y en todos sus elementos" ("Violencia, representación y voluntad realista").
} 
y las niñas de La vendedora - promete el placer de la diferencia, y al mismo tiempo se erige en una máquina productora de abyección, ansiedades y terror. ${ }^{35}$ Rosario, claro, no sobrevive mediante el rebusque como Mónica en La vendedora; se asemeja más a las novias de los pistolocos descritas en El peladito que no duró nada de Víctor Gaviria: adolescentes de barrio, de gran belleza, seducidas por el dinero del narcotráfico que las rodeaba de mercancías y lujos y las convertía en “escaparates” de distinción social y exhibicionismo. ${ }^{36}$

La diferencia es una fuente de promesas de placer. La subhumanidad del joven sicario, de la niña abandonada, de la mujer de la comuna, aparece como una invitación al consumo de esos cuerpos y al consumo de la lengua anómala que es metonimia de los mismos antes de que entren definitivamente en el espacio del desecho y antes de que esa lengua se normalice como mercancía del comercio erótico-lingüístico. El consumo del cuerpo de Rosario es paralelo al consumo, en el texto literario y en sectores de clase media y alta, de la lengua marginal de las comunas. El narrador de Rosario Tijeras aunque no asume el parlache, incorpora términos y giros del mismo. Alonso Salazar nota justamente la propagación del habla de las comunas entre otros grupos sociales:

No se sabe si por snob o por identidad, segmentos de jóvenes de clases medias y altas han incorporado a su vocabulario palabras heredadas del viejo lunfardo, travesuras lingüísticas de los camajanes y derivaciones del inglés cocinadas por los traqueteros. El lenguaje que brotó de las zonas oscuras se ha vuelto play ("VIOLENCIAS..." 124).

En Rosario Tijeras se equipara el cuerpo de Rosario al de la ciudad y, de nuevo, se da paso a la ambivalencia frente al cuerpo deseado y deseante de la alteridad:

Medellín es como esas matronas de antaño, llena de hijos, rezandera, piadosa y posesiva, pero también es madre seductora, puta exuberante y fulgorosa. El que se va vuelve, el que reniega se retracta, el que la insulta se disculpa y el que la agrede las paga. Algo muy extraño nos sucede con ella, porque a pesar del miedo que nos mete, de las ganas de largarnos que todos hemos tenido, a pesar de haberla matado muchas veces, Medellín siempre termina ganando (117).

A diferencia de la madre y la novia en Rodrigo $D$, o de los personajes de $L a$ vendedora; Rosario es una especie de equivalente femenino de Alexis (el sicario de $L a$ virgen), una máquina erótica de matar, ${ }^{37}$ una "puta exuberante y fulgorosa" entre el revólver y el labial. Como los sicarios y “pistolocos”, participa de ritos religiosos como

\footnotetext{
${ }^{35}$ El “Tijeras” de Rosario es una suerte de apodo que obtiene por haber castrado con esa herramienta al hombre que la violó.

${ }^{36}$ Tanto en Rodrigo D como en El peladito que no duró nada estas adolescentes aparecen como acompañantes de los pistolocos, muchos de los cuales sobrevivieron las riñas internas de pandillas y la guerra con el Estado y llegaron a convertirse en traquetos o incluso en grandes señores del narcotráfico.

${ }^{37}$ La construcción de Rosario como amante de traquetos (de los anónimos “duros” como se los llama en la novela) y partícipe del mismo tipo de actividades, la convierte en una especie de anomalía del género en la representación de la violencia.
} 
rezar las balas y cargar tres escapularios en lugares estratégicos del cuerpo para su protección; como ellos, su respuesta a cualquier provocación es acallar con el golpe seco y súbito de la muerte. De nuevo, en el cuerpo del Otro coinciden el objeto erótico y el dispositivo de la violencia.

Uno de los aspectos más problemáticos de estas novelas es precisamente lo que Mary Louise Pratt ha llamado, a propósito de La virgen de los sicarios-y de la relación entre el gramático y Alexis_-, la persistencia del “contrato sexual” en la novela. ${ }^{38}$ El cuerpo del Otro, llámeselo Alexis, Wílmar o Rosario, es pensado primero como mercancía ${ }^{39}$ y luego como femenino irracional caprichoso y salvaje, y fijado mediante la reiteración de estereotipos.

EL DESCENSO ANTROPOLÓGICO Y LA EPIFANÍA DE LA MIRADA

Jesús Martín-Barbero señalaba que los violentólogos han afiliado de manera casi mecánica la marginalidad social de la juventud de las comunas al crimen, la guerrilla y al sicariato, sin entender "la envergadura antropológica, es decir el espesor cultural de esas violencias, tanto de su origen como de su trama” (24). En 1990, casi coincidiendo con Rodrigo D, el jesuita y comunicador social Alonso Salazar publicó con el CINEP (Centro de investigación y educación popular) No nacimos pa' semilla, un texto difícil de clasificar. No nacimos está organizado como narración "testimonial” de una historia basada en varios relatos de "algunos de los protagonistas de la violencia”, a la vez que es también un estudio del "problema" desde el análisis de la "cultura de las bandas de Medellín”. Jesús Martín-Barbero celebra el trabajo y lo presenta como el primero que en este país se arriesga a investigar el mundo de las pandillas juveniles desde la cultura. Enfrentando la reducción de la violencia juvenil a efecto de la injusticia social, del desempleo, la violencia política y la facilidad de dinero que ofrecía el narcotráfico, la investigación de Salazar no ignora esas realidades pero muestra que la violencia juvenil se inscribe en un contexto más ancho y de más larga duración: el del complejo y delicado tejido sociocultural en que se insertan las violencias que atraviesan entera la vida cotidiana de la gente en Colombia y de la sociedad antioqueña en particular (24).

En No nacimos pa' semilla como en el trabajo de Gaviria encontraríamos una nueva mirada al desecho que en primer lugar desafía esa categoría. ${ }^{40}$ Pero, si bien escritor y

\footnotetext{
${ }^{38}$ En su ponencia, Pratt examina a partir de cinco novelas latinoamericanas publicadas en la década de los noventa (una de ellas, La virgen de los sicarios) la reconfiguración de la ciudadanía y la pertenencia social en la época neoliberal. Usa el concepto de pacto sexual (en contraposición a "El Contrato Social”) de Carole Pateman (The Sexual Contract) para examinar un nuevo orden monosexual donde lo femenino no ha desaparecido sino que se hace redundante.

${ }^{39}$ Recuérdese que el protagonista encuentra a Alexis en el apartamento de José Antonio en el cuarto de las mariposas en donde éste prostituye muchachos jóvenes de las comunas (Vallejo 10-12).

${ }^{40}$ Es importante señalar que Gaviria se opone drásticamente a que se denomine a estos jóvenes como “desechables” y afirma que su productividad cultural y económica no por marginal o criminalizada es inexistente pues estos ciudadanos crean sus propias formas de subsistencia y no mendigan ni esperan del resto de la sociedad (véase Suárez).
} 
cineasta proponen miradas críticas de la idea del desecho humano ${ }^{41}$ que contrastan con las visiones eróticas y profilácticas de la marginalidad económica y cultural de las comunas, se trata de dos proyectos narrativos diferentes.

Descontada la seriedad y la buena fe de No nacimos pa'semilla, es necesario contrastar el proyecto “redentor” y antropológico de Salazar con lo que ha sido visto de manera un poco contradictoria como la amoralidad y mirada involucrada (modo observacional) de la cámara de Gaviria. Mientras que Rodrigo D afirma y resignifica el “slogan” de la cultura punk declarando el “no futuro”, No nacimos pa' semilla, cuyo título expresaría en principio la misma idea, es sin embargo una denuncia, un memorial paternalista en contra de la declaración de no futuro. La de Salazar es una antropología evangélica que encuentra las causas de la descomposición social que produce la violencia en el desarraigo familiar y social, las desigualdades económicas y la perdida de valores trascendentales. El libro tiene un proyecto explicativo, de conversión y de salvación:

Hay que arrebatarle esta generación a la muerte, ese es el desafío... Nadie se puede negar a enfrentarlo. Por ahora, mi oficio es seguir acompañando la comunidad, a las familias, a las madres, en sus momentos difíciles. Ofrecerles mi solidaridad y mi palabra. Afortunadamente la imagen del sacerdote todavía es respetada. Y desde mi posición me relaciono con [...] los jóvenes de las bandas, para invitarlos a la vida (181).

Salazar advierte desde su posición que "Nuestro compromiso es afianzar la vida y la esperanza” (18). En otras palabras, No nacimos pa' semilla afirma que sí hay futuro, que toda humanidad es semilla, que es posible una solución a la aparente esterilidad de la vida de los sicarios, y que se trata, en fin, de comprender las causas y responder a ellas. Para Salazar, la respuesta sería un proyecto de disciplinamiento, socialización e inserción en el sistema productivo mediante políticas educativas y de empleo: "Yo digo que hace falta la ley, una autoridad que la gente respete. Pero sobre todo hay que abrir microempresas, famiempresas, grupos artísticos, clubes deportivos, mejorar las escuelas y los métodos pedagógicos, en fin mejorar las condiciones de vida” (181).

En contraste ni Rodrigo D ni La vendedora buscan una "solución al problema". Tampoco son proyectos de redención social. Cuando se le critica a Gaviria el poco efecto que sus películas tienen en la vida de sus actores en términos de “rehabilitación” social, éste responde:

Uno de los problemas éticos más serios que ofrece el trabajo con actores naturales es que a veces, como en los casos de Rodrigo $D$ o de La vendedora de rosas, se aprovechan las tragedias reales de seres humanos concretos. La película pasa y las tragedias continúan. La realización de la película no les cambia la vida a los niños. Es importante y éticamente necesario saber que algunos de mis actores han muerto en esas guerras amorfas que se

\footnotetext{
${ }^{41}$ Dice Martín-Barbero: "Desde esa mirada cambia el sentido en que los jóvenes sicarios constituyen el desecho de la sociedad, pues desechable significa tanto la proyección de la obsolescencia de que están hechos hoy la mayoría de objetos que produce hoy el mercado, como tiene que ver también con desecho, esto es, con aquello de lo que una sociedad se quiere deshacer... porque le incomoda, le estorba” (24-25).
} 
libran en Colombia; muchos siguen en la calle y son presa de la miseria y la droga. El hecho de que las películas no modifiquen la realidad no se le puede imputar al cine, aunque ello pese sobre uno [...] Yo no trabajo en la “educación” ni la "rehabilitación.” Hay instituciones dedicadas de buena fe a estas labores que se encargan —no sé si con mucho o poco éxito — de cambiar a estos muchachos sin modificar las circunstancias sociales y económicas en las que viven. El disciplinamiento, de cualquier manera, significa la destrucción de lo que me interesa ("Violencia, representación y voluntad realista”).

En Cómo poner a actuar pájaros Gaviria declara que el proceso de “educación” es un proceso mutuo — tanto para el grupo de jóvenes que participa en la película como para él mismo y su equipo de trabajo-y que se da a partir de la amistad.

La “solución” de No nacimos pa' semilla puede inaugurar una mirada crítica a la idea misma del desecho humano, como sugiere Martín-Barbero - y ciertamente se contrapone a la "solución" del exterminio propuesto por el narrador de la novela de Vallejo- pero su aproximación epistemológica a la alteridad asume que ésta debe y puede ser traducida. El último capítulo de No nacimos pa' semilla, por ejemplo, acomete una etiología de la violencia de los jóvenes de las comunas (181-211) y aventura hipótesis sobre sus causas. El libro trae además, como apéndice, un “Glosario” del léxico de las bandas (213-23). Rodrigo D y La vendedora, por el contrario, no sostienen la ilusión de aprehender la realidad-Otra; es más; estas películas parten de la renuncia a la inteligibilidad (traducción) de esa alteridad y al privilegio epistemológico de la comprensión de la misma.

Salazar y Gaviria ofrecen tipos muy diferentes de mirada. En el texto de Salazar existe un descenso y una mirada pía y redentora al desecho, mientras que en las películas de Gaviria hay una mirada-encuentro, que ni redime al Otro, ni lo re-significa como subalterno, pero tampoco se entrega al "simulacro posmoderno" y a la irrelevancia indolente de la "realidad”. Frente a la evanescencia de la imagen y el simulacro, la película produciría una mediación para el encuentro entre la mirada del espectador y el rostro del Otro, y así, una interpelación ética, sobre la cual es posible fundar un proyecto de derechos humanos.

Para Emmanuel Lévinas la ética se origina en el lugar del rostro del Otro. Es en la mirada como práctica del encuentro, que surge el imperativo de la responsabilidad; ${ }^{42}$ en el instante en que estoy frente a la cara del Otro, mi responsabilidad radical por éste se revela:

\footnotetext{
${ }^{42}$ Esta forma de relación ética de Lévinas tiene sus raíces en el concepto judío del mitzvah (mandamiento) y en la preocupación de la Torah por el bienestar del prójimo, especialmente aquel Otro violentado, impotente, abandonado, desprotegido, que se revela e impone su existencia con su mirada: el pobre, la viuda, el niño, el huérfano, el extranjero, el hambriento, todo ser humano que quiere ser reconocido como alguien y que me pide que lo reconozca y que sea alguien ante él y para él; todo aquel, en fin, que se nos (im)pone con sus miserias delante nuestro. Lévinas describe no sólo nuestra responsabilidad, y nuestro deber de respetar la diferencia, sino también la necesidad de colocar nuestra relación con el Otro en el centro de la vida, de entender la muerte no como "mi muerte" como lo hizo Heidegger sino como la muerte del Otro ("Ethics" 59-60).
} 
La aproximación del rostro es la forma más básica de responsabilidad. [...] El rostro no está en frente mío sino sobre mí; es el Otro antes de la muerte, mirando a través de, y haciendo manifiesta la muerte. En segunda instancia, el rostro es el Otro que me pide que no lo deje morir solo, como si de hacerlo me hiciera cómplice en su muerte. Entonces, el rostro me dice: no matarás. En relación con el rostro yo soy expuesto como usurpador del lugar del Otro. ("Ethics” 59-60)

La diferencia entre que alguien arroje un poco de basura a la calle o "elimine” esa basura y que arroje un niño o lo mate en una operación de "limpieza social”, es que en el segundo caso el rostro del Otro me emplaza. El encuentro con el rostro según Levinas, rompe el paradigma egótico de la subjetividad racional cartesiana y el individualismo liberal, y genera una responsabilidad que podemos evadir, pero a la cual no nos podemos sustraer.

El descenso epistemológico y / o político para la redención es problemático, como vimos en el caso del testimonio. Si bien "estamos obligados a preguntar quién es el otro, a tratar de definir objetivamente lo indefinible, a comparar lo incomparable" ("Ethics" 57), el Otro "no es desconocido sino incognoscible, [y] refractario a toda luz" ("Time and the Other" 43).

[Nuestra relación con el Otro] no es una relación idílica y armoniosa de comunión y simpatía, mediante la cual nos ponemos en el lugar del Otro; reconocemos al otro como parecido, pero exterior a nosotros; la relación con el Otro es una relación de Misterio ("Time and the Other" 43).

La traducción del gramático de La virgen es—como vimos—complementaria de las fantasías fascistas de profilaxis social y erradicación del desecho humano: "si las cosas son sólo cosas, es porque la relación con ellas es establecida como comprensión” (Lévinas, Basic Philosophical Writings 9). En las películas de Gaviria la responsabilidad ética es resultado del realismo o "voluntad realista” y de la coparticipación de los actores naturales en la narración fílmica. Gaviria intenta—si bien no siempre lo logra—una búsqueda común con el Otro, sin el paternalismo de un proyecto redentor ni disciplinario y sin la predisposición jerárquica a la traducción; asumiendo la incomprensibilidad y alteridad del Otro ${ }^{43}$ en otras palabras, se trata de un tipo de representación fundada en una observación mutua, en una óptica ética.

Cuando voy a rodar una película me dedicó a mirarlo todo con atención. A observar, aunque no suelo ser un buen observador. Pero cuando uno hace cine, está obligado a serlo. La vendedora de rosas es un trabajo de observación para darle sentido a un pedazo de la realidad colombiana, la realidad es caótica: parece no ir para ninguna parte. Pero al observar, uno vincula unas cosas con otras. Las conecta. ("No solo se ve con los ojos" 10B)

43 "Cuando el Otro entra en el horizonte del conocimiento ya ha renunciado a su alteridad” (Lévinas, Basic Philosophical Writings 12). "El Realismo afirma lo trascendente definiéndolo mediante la idea de ser, pero la idea de ser está fundamentalmente adecuada y ajustada a la mismidad” (12). Pero el Otro "no es convertible en lo ya conocido" (12). 
En una de sus declaraciones en el documental sobre la producción de La vendedora Gaviria reitera: "Íbamos en busca de una idea que sólo el rostro de la calle puede darnos" (Cómo poner a actuar pájaros). En contraste, La virgen de los sicarios expresa repugnancia por el "desecho humano" de las comunas o se deleita en la erótica de la alteridad y en su traducción constante; y No nacimos pa’ semilla moraliza, “estudia” y explica al Otro haciendo una diagnosis socio-cultural de los jóvenes sicarios. En Rodrigo $D$ y La vendedora esa juventud marginal ruidosa de las comunas participa incorporando sus "pequeños relatos" en ella y se resiste a ser cosificada como objeto estético, como alegoría política o como cuerpo-objeto erótico.

La vendedora rechaza el tropo del "desecho" y la "basura humana”; su realismo (efecto del trabajo con actores naturales y de la enunciación participativa) por el contrario, apunta a un encuentro inquietante — si bien mediatizado - con el rostro del otro. La participación de los actores naturales en la narración fílmica, la ininteligibilidad de la imagen y del lenguaje, la constante resistencia a la traducción y la alusión a la alteridad como externa al acto de representación, reinstalan la asechanza ética de lo "Real".

Como hemos visto, las diferencias entre los proyectos narrativos discutidos, si bien no son tajantes, sirven para caracterizar dos espacios discursivos. Por un lado están las traducciones, estetizaciones y apropiaciones eróticas y religiosas de la alteridad; el vouyerismo y el paternalismo, y una especie de re-apropiación o reciclaje de los residuos humanos y culturales del capitalismo en un simulacro que se regodea en la indiferencia. Por el otro, tenemos un trabajo que busca la participación de diversas agencias subalternas que afirman una humanidad no consumible, que desafían la traducción, que colocan en frente de la ciudadanía plena el desecho humano como alteridad y límite del ego consumo que define dicha ciudadanía.

\section{CiUdADANOS Y CONSUMIDOS}

La vendedora, como se recordará, comienza con un gran barrido de la cámara sobre las aguas de una cloaca de la ciudad de Medellín y termina con dos escenas en las que cuerpos humanos yacen arrojados entre la basura: el cadáver del Zarco está en uno de estos caños en donde se arrojan por igual las aguas negras y los “muñecos” o cadáveres; la última imagen es la del cuerpo de Mónica entre los escombros de lo que fuera la habitación de su abuela. Sin embargo, La vendedora no es una película sobre los desechos humanos sino contra la noción misma del desecho, lo que, por lo menos de manera parcial, se enuncia poniendo en jaque ético el concepto de ciudadanía.

Por su parte, Rodrigo D afirma en su "no futuro" el desastre de los desechos humanos de la sociedad posindustrial:

No futuro es una máxima del punk en todo el mundo. Indica la amenaza de la guerra nuclear, pero sobre todo el abandono que en la sociedad posindustrial se tiene para todo aquello que no sea la imagen de un producto consumible, devorable. No futuro es la máxima de lo que se ha llamado postmodernismo, el mundo de la publicidad, en donde todo se ha reducido a un enorme basurero. El tiempo se ha detenido en un presente consumible, en la inminencia del consumo (Gaviria "Un ojo de nadie” 4). 
Los “desechables” marcan los límites de la ciudadanía, esa asamblea de ciudadanosconsumidores que redefinen la esfera pública "posmoderna”44 (García Canclini 13-22). La inexistencia de los habitantes de las “cloacas” en el ágora de consumidores es complementaria de la fantasmagoría de sus imágenes — su vacío abismal. Tanto Rodrigo D. No futuro (1989) como La vendedora de rosas (1998) de Gaviria, redefinen dichos límites desde la vida cotidiana de esos consumidores consumidos que no alcanzan las felicidades de la ciudadanía "plena”.

Si García Canclini asegura que "las mercancías sirven para pensar” (48), Gaviria señala que sirven para morir:

\begin{abstract}
una serie de objetos y mercancías marcan cada momento de la acción en La vendedora: objetos que se degradan como el reloj que desencadena la muerte de la protagonista, los patines robados de la casa, la pólvora que se quema, o la mercadería barata que compran las niñas a un vendedor ambulante en el inquilinato. Las relaciones entre las mercancías degradadas, consumidas y los "desechables" como se les llama en Colombia a quienes viven en la calle, no fue un efecto consciente. No lo buscamos, pero así salió la cosa. El origen está en un relato que me contaron para un documental que hice: dos muchachos muy jóvenes y amigos habían, cada uno, robado un reloj. Uno había robado uno muy vistoso y bonito como para niña que el otro quería para su novia; así que los intercambiaron. Pero el muchacho que se quedó con el reloj de hombre trató de deshacer el negocio al poco tiempo; mientras se bañaba se le había dañado. Su amigo no le dijo que ya se lo había regalado a su novia y que le era imposible devolvérselo. La cosa terminó con que el dueño del reloj dañado mató de un tiro a su amigo. El lugar de la comunicación o del diálogo estaba ocupado por dos relojes que no valen la vida de nadie pero que valen su muerte ("Violencia, representación y voluntad realista").
\end{abstract}

Pero las películas de Gaviria no hacen una crítica culturalista y fascista de la cultura de masas (como el personaje-narrador de Vallejo), ni un reclamo evangélico (como el de Salazar contra la mercantilización de la cultura frente a cierta pérdida de valores trascendentes); su convocatoria ética no es frente a la mercantilización de la cultura sino la de la humanidad. En otras palabras, ponen en peligro el "milagro de la indiferencia" (como lo llama el director) por medio del cual puede hablarse de "desecho humano" y de "desechables", y aceptarse que miles de seres humanos puedan tener el mismo destino que la basura.

La máquina moderna de representación que es el cine, funciona aquí como una lente que rarifica la ciudad, redefiniéndola espacial, cultural y socialmente, recorriendo los límites de la lógica del capitalismo tardío en las periferias. La ciudad marcada por el consumo, la devoración y los desechos humanos, definida por una densa trama de exclusiones y escrita con los trazos caprichosos de la violencia, es también el espacio de la vida cotidiana, de la humanidad no reducible a objeto, de la afirmación de los vínculos societales, de solidaridad, y —más importante aún— el lugar de un encuentro mediático

${ }^{44}$ En Consumidores y ciudadanos García-Canclini le da forma a la propuesta de un modelo de encuentros culturales y de formación de identidades en América Latina. Allí sostiene que es mediante el consumo que se accede a la ciudadanía y que las culturas híbridas se producen y renuevan. El consumo sería la "razón comunicativa” de la nueva esfera pública. 
con el Otro, que intenta evitar la irrealidad del simulacro. En Gaviria encontramos de manera expresa una "ética de la representación" que no cae en la denuncia, ni en un neorrealismo panfletario sino que propone una suerte de pacto participativo de representación:

La película es apenas un conjunto de signos escritos; algunos de estos signos los escriben los protagonistas de estas vidas. Quisiera que la película fuera más que eso. Esa es la culpa que uno tiene y que asumo para hacer mi trabajo. Esta realidad me escandaliza y me desanima. Pero, por otra parte, me parece problemático hablar de lo excluido mediante actos de exclusión, es decir, hablar de los niños de la calle sin los niños de la calle, o de los sicarios sin los sicarios, o de los narcotraficantes sin sus relatos. Gracias a esta participación la película puede ser una obra colectiva. La enunciación colectiva le da una densidad a la película que me es muy difícil de alcanzar de otra manera ("Violencia, representación y voluntad realista”).

El trabajo de Gaviria estaría promoviendo un tipo de representación donde el “desecho humano" ocuparía momentáneamente un lugar hegemónico y reinstalaría la centralidad de la ética mediante una "mirada-encuentro":

Mi trabajo se dirige contra la idea del ciudadano escondido en su subjetividad, que no ve a nadie, que sólo vive en vecindad consigo mismo. [...] acaso esa niña pobre, sucia, "ignorante," alucinada, despojada de todo menos de su dignidad humana, sea quien te da la oportunidad única de salir de tu vecindario egótico ("Violencia, representación y voluntad realista").

Queremos sugerir que lo que se ha llamado “pornomiseria” en el cine de Gaviria corresponde al desasosiego que produce en el espectador el hecho de que el rostro que encontramos en estas películas no es imagen pura en la evanescencia del completo simulacro. Entre la mirada del espectador y la mirada de los personajes está, por supuesto, la mirada mediadora de la cámara; se trata de un encuentro mediatizado. Pero la imagen del Otro no es simulacro puro (es decir, no es un dispositivo para la indiferencia). El trabajo con actores naturales insiste en la "realidad", y en la exterioridad del acto de representación. En medio de las incertidumbres y de la evanescencia de los relatos de liberación, esta terca persistencia posibilita un "estado de vigilante insomnio" (Lévinas, "Ethics” 63) en el cual son posibles la ética y los derechos humanos, ${ }^{45}$ más allá del paternalismo redentor y más acá de la traducción de la otredad.

\footnotetext{
${ }^{45}$ Véase a este respecto, y como propuesta teórica, Crítica literaria como defensa de los derechos humanos: cuestión teórica de Hernán Vidal.
} 
Adorno, Theodor y Max Horkheimer. “The Culture Industry: Enlightenment as Mass Deception”. The Consumer Society Reader. Juliet Schor y Douglas B Holt, eds. Nueva York: New Press, 2000. 4-19.

Barthes, Roland. Mythologies. Nueva York: Hill and Wang, 1999.

Baudrillard, Jean. Selected Writings. Cambridge: Polity Press, 1988.

"Duelo". Illusion, désillusion esthétique. Mauricio Molina, trad. Paris: Sens \& Tonka, 1997. En Fractal 7 (2001): http://www.fractal.com.mx/F7baudri.html.

Beverley, John. Against Literature. Minneapolis: University of Minnesota Press, 1993. Subalternity and Representation. Arguments in Cultural Theory. Durham: Duke University Press, 1999.

Buñuel, Luis. Mi último suspiro. Barcelona: Plaza y Janés, 1987.

Burton, Julianne. “Toward a History of Social Documentary in Latin America”. The Social Documentary in Latin America. Julianne Burton, ed. Pittsburgh: University of Pittsburgh Press, 1989. 3-30.

Caicedo, Andrés. “Entrevista con Jorge Silva y Martha Rodríguez”. Ojo al cine. Seleccionado y anotado por Luis Ospina y Sandro Romero Rey. Bogotá: Grupo Editorial Norma, 1999. 403-14.

Chanan, Michael. "Rediscovering Documentary: Cultural Context and Intentionality". The Social Documentary in Latin America. Julianne Burton, ed. Pittsburgh: University of Pittsburgh Press, 1989. 31- 47.

Cómo poner a actuar pájaros (A propósito de la producción de La vendedora de rosas). Dir. Erwin Goggel, Sergio Navarro, Víctor Gaviria. Medellín: Televideo S.A, 1999.

“El nuevo cine colombiano. Entrevista con Ciro Durán, Mario Mitriotti, Carlos Álvarez, Jorge Silva, Luis Alfredo Sánchez y Marta Rodríguez. Hojas de cine. Testimonios y documentos del nuevo cine latinoamericano. Vol I. México, D.F.: Dirección General de Publicaciones y Medios, Secretaría de Educación Pública/Fundación Mexicana de Cineastas, A.C./Universidad Autónoma Metropolitana, 1988. 241-49.

Franco Ramos, Jorge. Rosario Tijeras. Bogotá: Plaza \& Janés, 1999.

García Canclini, Néstor. Consumidores y ciudadanos: conflictos multiculturales de la globalización. México: Grijalbo, 1995.

Gaviria, Víctor. El peladito que no duró nada. Bogotá: Planeta, 1991. "Helí Ramírez o la ausencia del descanso”. El pulso del cartógrafo. Medellín: Ediciones Autores Antioqueños, 1986. 119-24. "No solo se ve con los ojos". El tiempo (17 de agosto de 1998): 10B.

“Un ojo de nadie (reflexiones en torno a "No futuro")". Gaceta cine 34 (1989): 4. "Víctor Gaviria por Víctor Gaviria”. Revista Número 18. http:// www.revistanumero.com/18victor.htm.

"Violencia, representación y voluntad realista”. Entrevista con Víctor Gaviria. Carlos Jáuregui. Espacio Urbano, comunicación y violencia en Latinoamérica. Pittsburgh: IILI-Serie Tres Ríos, 2002. 
y Hugo Restrepo. Sumas y restas. Guión cinematográfico. Sin publicar.

Hess, John. "Neo-realism and New Latin American Cinema. Bicycle Thieves and Blood of the Condor”. Mediating Two Worlds: Cinematic Encounters in the Americas. John King, Ana María López, Manuel Alvarado, eds. British Film Insitute Publishing, 1993. 104-18.

Holston James y Arjun Appadurai. "Cities and Citizenship”. Cities and Citizenship. James Holston, ed. Durham: Duke University Press, 1999. 2-18.

Jaramillo, María Mercedes. “Fernando Vallejo, memorias insólitas”. Gaceta 42/43 (Enero/Abril 1998): 8-25.

Jáuregui, Carlos. "Del ca(n/l)ibalismo y la Antropofagia, al consumo”. Canibalismo revisitado: calibanismo, antropofagia cultural y consumo en América Latina. Disertación (Ph.D.) University of Pittsburgh, 2001.

La vendedora de rosas. Dir. Víctor Gaviria. Perf. Lady Tabarés. Producciones Filmamento, 1998.

La virgen de los sicarios. Dir. Barbet Schroeder. Perf. Germán Jaramillo, Anderson Ballesteros y Juan David Restrepo. Les Films du Losange, Canal + y Vértigo Films, 2000.

Lévinas, Emmanuel. Emmanuel Levinas: Basic Philosophical Writings. Adriaan T. Peperzak, Simon Critchley, Robert Bernasconi, eds. Bloomington: Indiana University Press, 1996.

"Ethics of the Infinite". Dialogues with Contemporary Continental Thinkers. Richard Kearney, ed. Manchester: Manchester University Press, 1984. 46-70.

“Time and the Other”. The Levinas Reader. Seán Hand, ed. Nueva York: Blackwell, 1989. 37-58.

López, Ana María. “At the Limits of Documentary: Hypertextual Transformation and The New Latin American Cinema”. The Social Documentary in Latin America. Julianne Burton, ed. Pittsburgh: University of Pittsburgh Press, 1989. 403-32.

Los Olvidados. Dir. Luis Buñuel. Perf. Alfonso Mejía, Miguel Inclán y Roberto Cobo. Ultramar Films, 1950.

Luzardo, Julio. “La Vendedora de Rosas, Largometraje Colombiano ¿Pornomiseria?” Enrodaje <<http://enrodaje.tripod.com/1cine.htm>> Octubre 27, 2001

Martín-Barbero, Jesús. "Jóvenes: des-orden cultural y palimpsestos de identidad”. "Viviendo a toda". Jóvenes, territorios culturales y nuevas sensibilidades. Humberto J. Cubides, María Cristina Laverde Toscano y Carlos Eduardo Valderrama, eds. Bogotá: Fundación Universidad Central, 1998. 22-37.

Muniz, Vik. Bienal XXIV de São Paulo de 1998.

Ospina, William. “No quiero morir pero matan”. Revista Número 26 (2000): 19-20.

Paz, Octavio. “El poeta Buñuel”. Las peras del olmo. México, DF: Imprenta Universitaria, 1957. 229-34.

Pratt, Mary Louise. “Tres incendios y dos mujeres extraviadas: El imaginario novelístico frente al nuevo contrato social”. Espacio Urbano, comunicación y violencia en Latinoamérica. Pittsburgh: IILI-Serie Tres Ríos, 2002. 
Rodrigo D, No futuro. Dir. Víctor Gaviria. Perf. Ramiro Meneses, Carlos Restrepo y Jackson Idrian. Focine, 1989.

Ranghelli, David. “El Neorrealismo y los niños en el cine latinoamericano”. Kinetoscopio 9/45 (1998): 9-13.

Salazar, Alonso. No nacimos pa’ semilla. Bogotá: CINEP, 1990.

"Violencias Juveniles: ¿Contraculturas o hegemonía de la cultura emergente?”. "Viviendo a toda”. Jóvenes, territorios culturales ynuevas sensibilidades. Humberto J. Cubides, María Cristina Laverde Toscano y Carlos Eduardo Valderrama, eds. Bogotá: Fundación Universidad Central, 1998. 110-28.

Suárez, Juana. "Bajo el lente de Gaviria”. Sitios de contienda: producción cultural colombiana en los umbrales del nuevo milenio. Disertación (Ph.D.) Arizona State University, 2000.

Sumas y restas (Publicidad para producción). Medellín: Ducha Fría Producciones, 2001. Vallejo, Fernando. La virgen de los sicarios. México: Alfaguara Hispánica, 1994.

Vidal, Hernán. Crítica literaria como defensa de los derechos humanos: cuestión teórica. Newark: J. de la Cuesta, 1994. 